\begin{tabular}{ccc}
\hline & JISE 10 (1) $2021: 102-108$ \\
UNNES & Journal of Innovative Science Education \\
http://journal.unnes.ac.id/sju/index.php/jise
\end{tabular}

\title{
Development of Teaching Materials "The Negative Effects of Electric Cigarette" As a High School Student Learning Source
}

\author{
Susi Erlianti ${ }^{\bowtie}$, Lisdiana Lisdiana $^{2}$, Priyantini Widiyaningrum $^{2}$ \\ ${ }^{1}$ SMA Ronggolawe Semarang, Indonesia \\ ${ }^{2}$ Pascasarjana, Universitas Negeri Semarang, Indonesia
}

\begin{tabular}{|c|c|}
\hline Article Info & Abstract \\
\hline $\begin{array}{l}\text { Article History : } \\
\text { Received June } 2020 \\
\text { Accepted July } 2020 \\
\text { Published April } 2021\end{array}$ & \multirow{3}{*}{$\begin{array}{l}\text { Lack of awareness and limited information about the dangers of e-cigarettes } \\
\text { among teenagers, especially high school students, make them assume that e- } \\
\text { cigarettes are a safe alternative to reduce smoking habit. This can be } \\
\text { circumvented through the development of teaching materials that are tailored } \\
\text { to the needs of students. This research aims to develop teaching materials about } \\
\text { the negative effects of e-cigarettes as a source of learning for high school } \\
\text { students and analyze their validity, readability, and feasibility. This } \\
\text { development research uses 4-D (Define, Design, Develop, Disseminate) } \\
\text { design. The subjects of this research include material and media experts, } \\
\text { students of class XI MIPA } 3 \text { and XI MIPA } 4 \text { SMAN } 12 \text { Semarang and teachers } \\
\text { who are members of senior high school biology teachers forum in Rembang } \\
\text { Regency. The results showed the validation scores of material and media } \\
\text { experts were } 83.00 \% \text { and } 97.70 \% \text {, respectively, with very valid criteria. } \\
\text { Analysis of the readability of teaching materials from the results of student } \\
\text { responses and the cloze test, respectively obtained an average score of } 86.20 \% \\
\text { and } 84 \% \text { with very good and independent criteria. Analysis of the feasibility of } \\
\text { teaching materials from the results of teacher responses at the senior high } \\
\text { school biology teachers forum in Rembang, obtained an average score of } \\
83.70 \% \text { with very feasible criteria. Based on the results of the research, it can } \\
\text { be concluded that teaching materials about the negative effects of e-cigarettes } \\
\text { are valid, it has good readability, and feasible to use as a source of learning for } \\
\text { high school students. The teaching material is expected to be able to add insight } \\
\text { and knowledge about the negative effects of e-cigarette exposure and to } \\
\text { contribute better in improving the quality of learning resources. }\end{array}$} \\
\hline $\begin{array}{l}\text { Keywords: } \\
\text { Teaching materials; } \\
\text { Electric Cigarettes; } \\
\text { Learning Source }\end{array}$ & \\
\hline & \\
\hline
\end{tabular}

correspondence :

SMA Ronggolawe Semarang, Indonesia

Jalan Damarwulan II No.103, Karangayu, Kecamatan Semarang

p-ISSN 2252-6412

Barat, Kota Semarang, Jawa Tengah, Indonesia 50142

E-mail: susierlianti@gmail.com 


\section{INTRODUCTION}

Smoking is still a problem that has not been resolved until now. Factors that can influence a person to smoke include peer factors, family factors, and psychological factors. Based on these factors, it's clearly not an easy thing for smokers to quit or reduce smoking. There are several ways you can do one of them by switching to electric cigarettes.

Electric cigarettes are designed to help tobacco smokers start to stop smoking slowly (Brown et al., 2014). In Indonesia, e-cigarettes are increasingly in demand (BPOM, 2015). However, according to Dutra et al., (2016) along with the increasing popularity of e-cigarettes, it will actually trigger an increase in the number of smokers, especially among teenagers. In 2010, WHO no longer recommended ecigarettes as NRT because they did not meet the safety element. Lack of awareness and limited information about the dangers of e-cigarettes among students, makes them think e-cigarettes are a safe alternative to reducing smoking.

Based on a questionnaire analysis of perceptions about e-cigarettes with respondents from 63 high school students in Semarang, found $41.00 \%$ of students thought e-cigarettes had a safer effect compared to tobacco cigarettes, $48.00 \%$ of students stated that e-cigarette smoke was better inhaled than tobacco smoke, even though without them realize in a certain period of time the smoke exposure can cause health problems. This lack of awareness can be circumvented through learning in schools. Learning is expected to give an impression to students and increase knowledge. The learning process will take place well if the components of learning are fulfilled. One component that must be present in learning is a learning resource. One type of learning resource is teaching material. Teaching material is a guide for teachers and students in directing their activities towards learning and contributing well in helping students to learn independently (Lau et al., 2017). The design of good teaching materials can be used as a starting point for efforts to improve the quality of learning.

Based on the analysis of teaching materials for class XI high school students, it is known that SMA 12 Semarang provides teaching materials in the form of textbooks and worksheets to support the learning process. Teaching materials found mainly in several chapters of the body's system, sub-section abnormalities or disorders contain material briefly. The new teaching material provides general information, not yet applying examples that are linked to problems with students, for example issues about the dangers of exposure to electric cigarettes. The teaching material used there is a discussion about cigarettes, but there is still minimal information. Actually, the school has given a ban on smoking to students, but in reality still found students who bring tobacco cigarettes or electric cigarettes to school. This is evidenced by the existence of 14 cases of students smoking in January 2020 and 11 cases of students bringing cigarettes to school in February 2020. Based on the results of a questionnaire analysis of student needs, it was found that $46 \%$ of students still did not know much about the dangers of electric cigarettes. As many as $85 \%$ of students think it is necessary to develop teaching materials that discuss in detail about the dangers of exposure to electric cigarettes.

Based on the background above, this study aims to develop teaching materials about the negative effects of electric cigarettes as a source of learning for high school students. The teaching material developed can be used as a supplementary book, bearing in mind the 2013 Curriculum student textbooks used as the main reference, not yet including examples that are linked to problems among teenagers especially high school students.

\section{METHODS}

This research is a development research that follows the Thiagarajan et al. (1974). The development consists of four stages, namely define, design, develop and disseminate. This research has been carried out at the postgraduate faculty of UNNES and tested at SMAN 12 Semarang in the even semester of the 2019/2020 school year and at the senior high school biology teachers forum in Rembang regency.

The data in this research included problem analysis data obtained through students' perception questionnaire on electric cigarettes and student needs analysis questionnaire on teaching materials distributed to 63 students of class XI MIPA 1 and XI MIPA 2 at SMAN 12 Semarang; data of the validity of teaching materials obtained through the questionnaire validation of material and media given to expert lecturers; data readability of teaching 
materials obtained through student questionnaire responses and cloze test distributed to 63 students of XI MIPA 3 and XI MIPA 4 SMAN 12 Semarang; as well as the feasibility of teaching material data obtained through teacher questionnaire responses that are incorporated in the senior high school biology teachers forum in Rembang regency. The data was analyzed by descriptive quantitative percentage.

\section{RESULTS AND DISCUSSION}

\section{The Validity of Teaching Materials "the Negative Effects of Electric Cigarettes" as a High School Student Learning Source}

The validity of teaching materials is determined based on the assessment of material experts and media experts. Teaching material is declared valid if the assessment of material experts and media experts reaches an average percentage score of $>62.00 \%$ or within valid and very valid criteria. The validation stage by the material experts obtained an average percentage score of $83.00 \%$ with very valid criteria. Material experts assess the validity of teaching materials based on the components of material feasibility, linguistic and contextuality. In the component of material feasibility obtained an average score of each aspect at $84.40 \%$. Material experts assess the presentation of teaching materials can foster enthusiasm and interest in student learning, because the material is adjusted to the problems that occur in everyday life so as to raise high curiosity. Teaching materials are also equipped with motivational words, which are expected to have a positive influence on students to be more aware of the dangers of e-cigarettes. Teaching material presents material concepts from easy to difficult, simple to complex. The principle of presenting the material can create a meaningful learning atmosphere (Sahabuddin \& Makkasau, 2019). In addition, the illustrations and images presented help to clarify the material description of teaching materials (Farida et al., 2018).

In the linguistic component, the average score for each aspect is $75.00 \%$. This shows that teaching materials are adjusted to the level of students' language, so as to create understanding of the material presented. Suswina (2011) states that the instructional materials compiled are interesting but do not use grammar that is easily understood, so it can be said that the teaching materials are less effective in creating meaningful learning. In the contextual component all aspects of the assessment get the maximum score. Teaching material developed has advantages, namely containing research results that are contextual to the daily lives of students. This can encourage students to make connections between their knowledge and their daily lives and can increase student activities (Surata et al., 2019). Even though it has been considered very valid, teaching materials still need improvement. Suggestions from material experts include improving the typography of teaching material writing, adding material from the latest and related journals, and refining material in the structural histology section of the lungs.

After evaluating the validity of the material, the next step is to assess the validity of the teaching material media. The validation stage by media experts obtained an average score of $97.70 \%$ with very valid criteria. The assessment is based on the presentation and graphic components which consist of several aspects, including presentation techniques, supporting material presentation, teaching material size, teaching material cover, and content design. In the aspect of presentation techniques, supporting the presentation of material, the size of teaching materials, and the cover of teaching materials get the maximum score. This is because teaching materials have a systematic presentation consistency. Teaching materials about the negative effects of electric cigarettes are arranged into three parts, namely Front Matter, Text Matter, and End Matter. The presentation framework is arranged in a coherent and systematic manner so as to facilitate students in using teaching materials. Wati et al. (2015) argues teaching materials that have a complete presentation technique, coherent according to the concepts discussed and are consistent, will make it easier for students to understand the contents of the message delivered. Some of the pictures in teaching materials are the result of personal documentation while observing in the field, so that they can present factual information and increase students' enthusiasm when learning. Teaching materials have a size that is in accordance with ISO standards, namely B5 (176 X $250 \mathrm{~mm})$. Besides the cover appearance can reflect the contents of teaching materials. 
In the design aspect, the contents obtained an average score of $94.60 \%$. Although they do not get the maximum score as in the other four aspects, media experts consider that the design of instructional content is structured and makes it easier for readers to learn teaching material. The presentation of the contents of teaching materials is complete so that it helps both teachers and students in order to increase knowledge about e-cigarettes and their impact on physical health. Even though it has been considered very valid, according to media experts there are still a number of components that need to be added, so teaching materials still need improvement. Media experts suggest adding concept maps to teaching materials. Concept maps are considered to be able to improve students' understanding of the concept of the material, so that it affects their academic achievement improvement (Liu et al., 2014). In addition to adding concept maps, teaching materials are suggested not only to be informative but also to provide opportunities for students to develop their thinking skills. Teaching material with these characteristics is expected to train students' independence in learning (Arafah et al., 2012). Teaching materials are designed to attract students' attention, for this reason a combination of writing, tables, pictures, graphics, or flowcharts is needed. The teaching material developed already contains components of tables, figures, and graphs but there is no flowchart, so it needs to add a flowchart to the content of the teaching material. According to Hooshyar et al. (2015), flowcharts make it easier for students to understand the material and can improve students' ability to solve problems. From the assessment of material experts and media experts, it can be concluded that teaching materials about the negative effects of e-cigarettes have been rated very valid with some improvements.

\section{Readability of Teaching Materials "the Negative Effects of Electric Cigarettes" as a High School Student Learning Source}

Readability of teaching materials is based on student responses and the overlap test. Teaching material is said to have good readability if the student questionnaire score is at least $>62.00 \%$ or in good and very good criteria; and the score of cloze test between at least $41-60 \%$ or within instructional and independent criteria.
Based on the questionnaire responses that were distributed to 63 students of Class XI MIPA 3 \& XI MIPA 4 SMAN 12 Semarang, an average percentage score of $86.20 \%$ was obtained or in very good criteria. The assessment is based on aspects of readability, easiness, attractiveness, comprehension, and effectiveness. The attractiveness aspect gained the highest average score of $87.70 \%$. This is because according to the students the images presented have color clarity and proportional layout. Students are interested in some pictures which are personal documentation of observations in the field. Students also argue that the information contained in teaching materials is complete. According to Arlitasari et al. (2013) and Norsalisa et al. (2013) states that the presentation of attractive teaching materials both in terms of pictures and writing can increase student interest in learning \& understanding.

In the aspect of easiness of getting the lowest average score when compared with other aspects that is equal to $84.80 \%$. This is because according to one student teaching materials can already be used, but there are some terms that cannot be understood. In addition to the two aspects above, other aspects get an average score above $85 \%$. Most students assume the teaching material developed is interesting, effectively used to increase knowledge about ecigarettes and their impact on physical health, and can increase curiosity. This is in line with the opinion of Nugraha et al. (2013) and Khoiri (2014) which stated that students' interest in teaching materials would make it easier for students to understand the material and foster curiosity.

From the results of the analysis of the responses, students also provide comments and suggestions. According to students, teaching materials need to be added to quiz, which are intended to find out how far students understand after reading teaching material. Quiz are also expected to encourage students to be more active in learning. Students also commented on the presentation of teaching materials too many writings with a large number of pages. This is because teaching materials contain some material in class XI, namely respiration system material, circulation system, and immune system, each of which is associated with the danger of exposure to e-cigarettes through relevant studies, so teaching material has a large number of pages. Teaching materials are expected to increase students' understanding of the 
negative effects of e-cigarettes on body health through the research included in teaching materials. This is supported by the opinions of Wulandari et al. (2017) which states research-based teaching materials can increase learning success for students.

In addition to being obtained from students' responses, the readability of teaching materials is also obtained from the cloze test. Students are asked to do a cloze test by filling in the blanks of words from several paragraphs in a reading (Sabarua, 2018). Cloze test was distributed to 10 students from XI MIPA 3 and XI MIPA 4 classes in SMA Negeri 12 Semarang with different levels of ability (4 students with high academic categories, 3 students with medium academic categories, and 3 students with low academic categories). The selection of students with the help of teachers is based on the Biology Daily Test scores. Recapitulation of student cloze test results can be seen in Table 1 as follows.

Table 1. Recapitulation of Student Cloze Test Results

\begin{tabular}{lll}
\hline $\begin{array}{l}\text { Academic Category } \\
\text { of Respondents }\end{array}$ & $\begin{array}{l}\text { Score } \\
\text { Percentage } \\
(\%)\end{array}$ & Criteria \\
\hline High & 95 & Independent \\
Medium & 82 & Independent \\
Low & 72 & Independent \\
\hline Average percentage & 84 & Independent \\
\hline
\end{tabular}

The results of the analysis of the cloze test obtained an average percentage score of $84.00 \%$ or within independent criteria. The acquisition of the score shows that the learning materials are easily understood by students and can be used independently. In Table 1 it is known that students in the lower middle academic category get the lowest average score. This is because one of the students got the lowest score when compared to the scores of other students. According to Slameto (2010), there are seven psychological factors that can influence students to learn, namely intelligence, attention, interest, talent, motives, maturity, and fatigue. If based on the time of work, the low score is due to factors of attention and fatigue. Cloze tests are distributed to students at night and are done online, so that students are worried that they will feel tired and not concentrate after doing learning activities from the morning which are also done online.

The Feasibility of Teaching Materials "the Negative Effects of Electric Cigarettes" as a High School Student Learning Source

The feasibility of teaching materials is based on the teacher's response at the senior high school biology teacher's forum in Rembang Regency. Teaching material is said to be feasible if the teacher's response at the senior high school biology teacher's forum at least $>62 \%$ in the feasible criteria and very feasible. The assessment of the feasibility of teaching materials is based on aspects of the feasibility of content, presentation, linguistic, graphic and contextuality aspects. Based on the questionnaire the feasibility of teaching materials provided to teachers, as many as 16 teachers have responded. The results of teacher responses found an average score of $83.70 \%$ with very feasible criteria. The scores on each component of the teacher's assessment of the feasibility of teaching materials are presented in graphical form as in Figure 1 as follows.

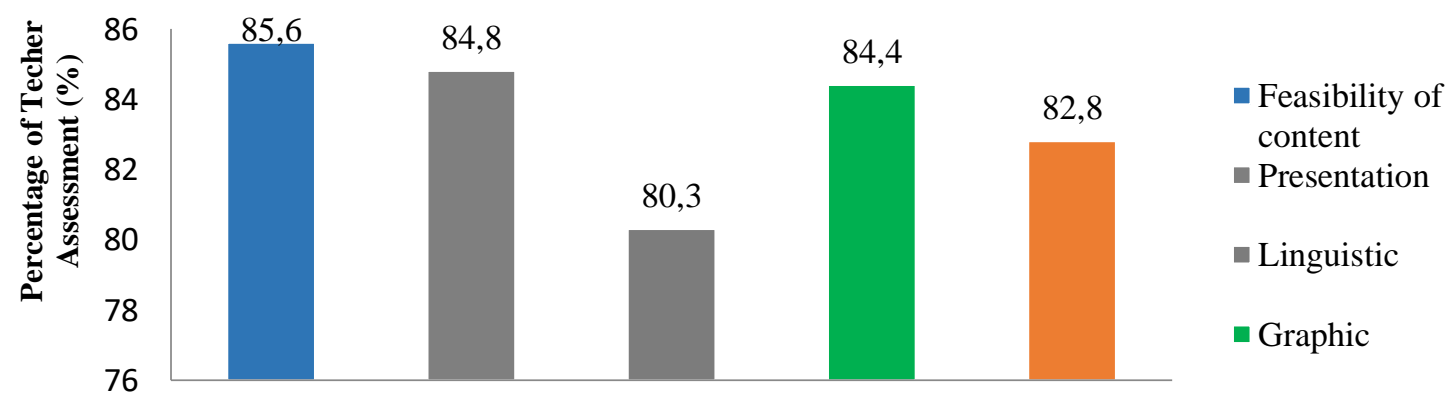

Teacher Assessment Components

Figure 1. Graph of Teacher Assessment Results

The graph above shows the highest average percentage score, which is the content feasibility component of $85.60 \%$. This is because according to the teacher, the teaching material developed is able 
to introduce a causal relationship. Teaching materials are said to be able to introduce a causal relationship because there are material reviews about e-cigarettes and the effects caused by their use. Examples and cases that are presented are in accordance with reality and are sourced from credible media so as to support increased student knowledge. Teaching material developed is considered attractive because it is equipped with pictures that are compatible with the material. Septiani et al. (2013) mentioned that instructional materials that are designed to be interesting and equipped with images will be impressed not monotonous so as to attract student learning interest. This is also supported by the opinions of Anindityas et al. (2012) which states that pictures can help students to see clearly about what is learned so as to increase interest and learning outcomes.

The teacher assumes that teaching material is developed based on contextual or contains facts related to daily life and the material is presented upto-date or according to the needs and development of students. According to Widarti et al. (2013) with the application of contextuality in the learning process it will create interesting and fun learning, but still prioritize understanding of the material. Lestari et al. (2017) states teaching materials that contain contextual elements can increase student activity and involvement in learning.

The results of the teacher assessment analysis showed that the linguistic component obtained the lowest average score, which was $80.30 \%$. This is because according to the teacher's response, in developing teaching materials should pay more attention to the use of words or terms with the aim that teaching materials can be understood in various cognitive circles of students. The teacher mentioned that students were interested in discussions about cigarettes, both electric cigarettes and tobacco cigarettes. Often students ask questions about smoking to the teacher. So that the development of this teaching material is considered to help answer students' curiosity. Based on the analysis of teacher responses, the overall results are obtained that the developed teaching material is suitable for use by high school students, and can complement the learning materials that are already available in schools. Although it has been assessed as very feasible, according to the teacher there are still several components that need to be added, so the teaching materials still need improvement.

The teacher suggests that teaching materials need to be added to the concept map for each subtopic. This aims to facilitate students in understanding the material to be studied in each chapter. Actually in the validity test, media experts have suggested to add a concept map, but the concept map in question is a concept map that covers the entirety of the material contained in teaching materials. Concept maps facilitate students to strengthen theory and understanding so that misconceptions do not occur (Wilson et al., 2016).

The teacher adds the illustration of the picture on the cover page still needs improvement. The image display is less clear, so it needs to be improved with a more precise image and can reflect the contents of the teaching material. In addition, the teacher also suggests improving the title of teaching materials. According to one of the teachers the initial title of teaching material that is "Electric Cigarettes: Healthy or Suffering" is considered to be contradictory and has a negative impression. The teacher gives input to the improvement of the teaching material title, "Electric Cigarettes: Recognize and Avoid to Save Indonesian Young Generation".

The teacher also said that the need to add a graphic picture of breathing air volume to the lungs, because the graph is often discussed in practice questions. In addition, the teacher assesses that there are several paragraphs that are too long which should be separated into two paragraphs. Some teachers think that the material presented in teaching materials is too much or too dense. As explained earlier, teaching material discusses the negative effects of e-cigarettes associated with class XI student material, namely the respiration system, circulation system, and immune system, where each subject is also equipped with research results in the hope that students can learn through fact.

\section{CONCLUSION}

Based on the results and discussion, it can be concluded that teaching materials about the negative effects of electric cigarettes are valid, it has good readability, and feasible to use as a source of learning for high school students. 


\section{REFERENCES}

Anindityas, N.A., Utami, N.R., \& Widiyaningrum, P. (2012). "Penggunaan Alat Peraga Sistem Pernapasan Manusia pada Kualitas Belajar Siswa SMP Kelas VII". Unnes Science Education Journal, 1 (2), 60-69.

Arafah, S.F., Ridlo, S., \& Priyono, B. (2012). "Pengembangan LKS Berbasis Berpikir Kritis pada Materi Animalia". Unnes Journal of Biology Education, 1 (1), 47-53.

Arlitasari, O., Pujayanto, \& Budiharti, R. (2013). "Pengembangan Bahan Ajar IPA Terpadu Bebasis Salingtemas dengan Tema Biomassa Sumber Energi Alternatif Terbarukan". Jurnal Pendidikan Fisika, 1 (1), 81-89.

Brown, J., Beard, E., Kotz, D., Michie, S., \& West, R. (2014). "Real-World Effectiveness of E-Cigarettes When Used to Aid Smoking Cessation: A CrossSectional Population Study". Addiction, 109 (9).

Dutra, L.M., Grana, R., \& Glantz, S.A. (2016). "Philip Morris Research on Precursors to The Modern ECigarette Since 1990". Tobacco Control, 1-9.

Farida, Khoirunnisa, Y., \& Putra, R.W.Y. (2018). "Pengembangan Bahan Ajar Gamifikasi pada Materi Bangun Ruang Sisi Lengkung”. JPPM, 11 (2), 193-204

Hooshyar, D., Ahmad, R.B., Yousefi, M., Yusop, F.D., \& Horng, S.J. (2015). "A Flowchart-Based Intelligent Tutoring System for Improving Problem-Solving Skills of Novice Programmers". Journal of Computer Assisted Learning, 3 (1), 345-361.

Khoiri, A. (2014). "Pengembangan Bahan Ajar Fisika SMK Berbasis Potensi Lokal untuk Menumbuhkan Soft Skills Siswa". Journal of Innovative Science Education, 3 (1), 1-9.

Lau, K.H., Lam, T., Kam, B.H., Nkhoma, Richardson, M., J., \& Thomas, S. (2017). "The Role of Textbook Learning Resources in E-Learning: A Taxonomic Study". Computers \& Education.

Lestari, A., Amelia, E., \& Marianingsih, P. (2017). "Pengembangan Lembar Kerja Siswa Berbasis CTL (Contextual Teaching And Learning) sebagai Bahan Ajar Siswa SMA/MA Kelas XII Subkonsep Kultur In Vitro. Biosfer: Jurnal Pendidikan Biologi (BiosferJPB), 10 (1), 32-44.

Liu, Y., Zhao, G., Ma, G., \& Bo, Y. (2014). "The Effect of Mind Mapping on Teaching and Learning : A Meta-Analysis". Standart Journal of Education and Essay, 2 (1), 17-31.

Norsalisa, E., Widiyaningrum, P., \& Lisdiana. (2013). "Pengembangan Media Pembelajaran Zat Adiktif dan Psikotropika Berbentuk Komik Kontekstual di
SMP". Journal of Innovative Science Education, 2 (1), 1-7.

Nugraha, E.A., Yulianti, D., \& Khanafiyah, S. (2013). "Pembuatan Bahan Ajar Komik Sains Inkuiri Materi Benda untuk Mengembangkan Karakter Siswa Kelas IV SD". Unnes Physics Education Journal, 2 (1), 1-9.

Sabarua, J.O. (2018). Implementasi Teknik Uji Rumpang pada Pembelajaran Bahasa Indonesia di Sekolah Dasar. http:// https://osf.io/428fm/. pdf (diunduh 22 Oktober 2019).

Sahabuddin, E.S., \& Makkasau, A. (2019). "Pengembangan Perangkat Pembelajaran Karakter Berbasis Kearifan Lokal". Prosiding Seminar Nasional LP2M UNM, 577-580.

Septiani, D., Ridlo, S., \& Setiati, N. (2013). "Pengembangan Lembar Kerja Siswa Berbasis Multiple Intelligences pada Materi Pertumbuhan dan Perkembangan". Unnes Journal of Biology Education, 2 (3), 359-365.

Slameto. (2010). Belajar dan Faktor-faktor yang Mempengaruhinya. Jakarta: PT Rineka Cipta.

Surata, I.K., \& Marhaeni, I.G.A.A.N.D. (2019). "Pendekatan Contextual Teaching and Learning (CTL) Berbasis Lembar Kerja Peserta Didik (LKS) untuk Meningkatkan Aktivitas Belajar Biologi”. Bioedusiana, 4 (2), 114-121.

Suswina, M. (2011). "Hasil Validitas Pengembangan Bahan Ajar Bergambar Disertai Peta Konsep untuk Pembelajaran Biologi SMA Semester 1 Kelas XI". Ta'dib, 14 (1), 44-51.

Thiagarajan, S., Semmel, D., \& Semmel, M. (1974). Instructional Development for Training Teacher of Exceptional Children. Washington D.C: National Center for Improvement of Exceptional System.

Wati, H.M., Susantini, E., \& Rahayu, Y.S. (2015). "Validitas Bahan Ajar Berbasis Metakognitif pada Materi Anabolisme Karbohidrat". BioEdu, 4 (3), 957-962.

Widarti, S., Peniati, E., \& Widiyaningrum, P. (2013). "Pembelajaran Gallery Walk Berpendekatan Contextual Teaching and Lerning Materi Sistem Pencernaan di SMA". Unnes Journal of Biology Education, 2 (1), 11-18.

Wilson, K., Solas, E.C., \& Dixon, N.G. (2016). "A Preliminary Study on the use of Mind Mapping as a Visual-Learning Strategy in General Education Science Classes for Arabic Speakers in the United Arab Emirates". Journal of The Scholarship of Teaching And Learning, 16 (1), 31-52.

Wulandari, Widiyaningrum, P., \& Setiati, N. (2017). "Pengembangan Suplemen Bahan Ajar Biologi Berbasis Riset Identifikasi Bakteri untuk Siswa SMA". Journal of Innovative Science Education, 6 (2), 155-161. 